\title{
Indicators of sustainable development for catchment management in South Africa - Review of indicators from around the world
}

\author{
Jay Walmsley ${ }^{1 \star}$, Mark Carden ${ }^{2}$, Carmen Revenga ${ }^{3}$, Frank Sagona ${ }^{4}$ and Malcolm Smith ${ }^{5}$ \\ ${ }^{1}$ Mzuri Consultants, PO Box 72847, Lynnwood Ridge, 0040, South Africa \\ ${ }^{2}$ Murray-Darling Basin Commission, GPO 409, Canberra, ACT 2601, Australia \\ ${ }^{3}$ World Resources Institute, $10 \mathrm{G}$ Street, NE Suite 800, Washington DC, 20002, USA \\ ${ }^{4}$ Tennessee Valley Authority, 1101 Market Street, Room CST17D, Chattanooga TN 37401, USA \\ ${ }^{5}$ Fraser Basin Council, Suite 1257-409 Granville St, Vancouver BC, V6C 1T2, Canada
}

\begin{abstract}
Indicators are the ideal means by which progress towards sustainable development can be measured. However, most indicator initiatives throughout the world have been aimed at state-of-the-environment reporting, with relatively few aimed at developing sectoral indicators. This paper provides the results of a review to establish trends in the development of indicators that assist in integrated water resource management. Twenty-one organisations from around the world were approached with regard to whether they had developed indicators of sustainable development for catchment management. Of these, only five organisations had developed, or were in the process of developing, indicator sets that were available for review. These included the Fraser Basin Council (Canada), the Murray-Darling Basin Commission (Australia), the Tennessee Valley Authority (USA), the United States Environmental Protection Agency and the World Resources Institute. All of these indicator sets were developed using an issuesbased approach. Each indicator set was unique, reflecting the policy, both national and organisational, upon which it had been based. An analysis of these five indicator sets revealed that the most important themes that required information for water resource management at a catchment level, were biodiversity and ecosystem integrity, land-use change, water quality, waste production, water availability and resource use. Common indicators included population growth; community involvement; water availability; water use; water quality trends; soil contamination; non-compliance; species at risk; key species assessment; change in vegetation; agricultural impact; access to recreational opportunities, and ecosystem health. The identification of these themes and common indicators will be useful for the development of indicators for catchment management in South Africa. More importantly, policy frameworks and the physical characteristics of catchment systems in the country need to be taken into account. Additionally, it is recognised that no effective indicator set can be developed without the input of stakeholders.
\end{abstract}

\begin{abstract}
Introduction
Sound water resource management is one of the key components of sustainable development as advocated by Agenda 21 (Chapter 18). In the last 10 years, governments throughout the world have reviewed their policies so as to achieve sustainability of water resources. In particular, the South African government has introduced the National Water Act (No. 36 of 1998), which will effectively dictate water resource policy and practice for at least the next 10 years. A core feature of this Act is the introduction of catchment management agencies that will be responsible for integrated water resource management of specific catchments. Catchment management strategies are to be developed for each catchment in South Africa to ensure that the water resources are utilised in a sustainable manner. Additionally, the Act (Chapter 14) requires that the Government establish a national monitoring and information system for water resources as soon as possible. This system should provide for the collection of appropriate data to assess the quantity, quality, use and rehabilitation of water resources at catchment and national levels, as well as compliance with resource quality objectives, health of aquatic ecosystems and atmospheric conditions that may impact on water resources.
\end{abstract}

\footnotetext{
* To whom all correspondence should be addressed.

푱(012) 361-2924; fax (012) 361-9845; e-mail mzuri@pixie.co.za

Received 22 March 2001; accepted in revised form 16 August 2001.
}

Indicators are the ideal means by which progress towards a goal, in this case integrated water resource management, can be monitored. Indicators provide a summary of conditions, rather like temperature and blood pressure are used to measure human health. They have been used for many years by economists to explain economic trends, a typical example being Gross National Product, but have only fairly recently been introduced to determine the sustainability of environmental systems as required by Agenda 21 (e.g. OECD, 1993; MacGillivray, 1994; Gouzee et al., 1995; Hammond et al., 1995; Trzyna, 1995; World Bank, 1995; Bakkes et al., 1994; Moldan and Billharz, 1997).

Most indicator initiatives have been aimed at providing information at a national level for state-of-the-environment reporting (e.g. Ward, 1990; OECD, 1991; ANZECC, 1998; GRID-Arendal, 2000) or for answering specific policy questions at national and international levels (e.g. UNEP and WHO, 1988; FAO, 1992; Eeronheimo et al., 1997). Few initiatives have been aimed at developing sectoral indicators, although some attempt has been made to develop sectoral indicators for agriculture, forestry, transport and energy (Obst, 2000). In South Africa, indicators are currently being developed for national state-of-the-environment reporting (CSIR et al., 2001) and for forestry (NFAC, 2001). It is uncertain to what extent an attempt has been made to develop indicators for catchment or water basin management, either within South Africa or internationally. This paper provides the results of a review to establish what progress has been made towards development of 
indicators that assist in catchment management. The focus is on the approach taken by various organisations throughout the world; the indicator sets developed by them, and the lessons that can be learnt from these for the development of sustainability indicators for catchments.

\section{Methodology}

A literature and internet search was conducted to identify organisations around the world that might be involved in catchment management directly, or which might have addressed the problem of information management at a catchment or watershed level. Four types of organisations were identified:

- Catchment management agencies (CMAs), which were directly involved in catchment management and had an official mandate to manage the water resources of the catchment areas for which they were responsible. These were identified through recognition of the catchment areas for which they were responsible (i.e. Tennessee River; Vaal River; Murray-Darling River).

- Non-governmental organisations and international basin commissions, which were associated with specific catchment areas, but did not have an official mandate to manage any of the catchment areas. In most cases, they were advisory bodies that were established to provide insight into catchment management issues. As with the CMAs, they were identified through recognition of the catchment areas for which they were responsible (e.g. Rhine River; Fraser River; Danube River).

- Government agencies and departments, which were not related to specific catchment areas, but which had an interest in catchment management as part of their mandate or complementary to their mandate. For example, the CSIRO had a research responsibility as part of its Sustainable Catchment Management Program, the UK Environment Agency had a responsibility to the environment, including river basins and the South African Department of Water Affairs and Forestry (DWAF) had a legal responsibility to ensure sustainable catchment management.

- International organisations, which were involved in the management of the environment and natural resources, including water.

Although it was recognised that these organisations were at different levels of governance, they all had an interest in managing catchments sustainably. Because catchments can be defined by similar characteristics (watersheds defining the boundaries, fourdimensional nature etc.; Wells, 1992), it was accepted that there was a basis for comparison. Additionally, water resource management is not only based on management objectives, but is largely dependent on the condition of the catchment, which can be assessed using sustainability indicators.

In all, 21 organisations were approached with regard to whether they had developed indicators of sustainable development for catchment management (5 CMAs; 6 NGOs and international basin commissions; 7 government agencies and departments, and 3 international organisations). A contact person was identified for each organisation and requested to provide information on any programme or programmes to develop indicators for catchment management, including:

- The policy requirements and mandate of the organisation

- The process followed to develop indicator sets
- Lists of indicators that might depict catchment health; catchment management; condition of water resources in the catchment, and sustainability of catchment systems.

The information provided by the response organisations was reviewed and indicator sets were compared to each other. Common indicators were identified, and the differences between indicator sets were established. The different approaches to the establishment of indicators were noted and commented upon where possible. Lessons to be learnt for development of catchment management indicators in South Africa were extracted and commented upon.

\section{Results}

Of the 21 organisations approached, 18 replied. Of these, $12(67 \%)$ had not developed a set of indicators for catchment management, and $6(33 \%)$ had either developed a set or were in the process of developing a set (Table 1). The organisations for which indicators were available for review, included:

\section{- Fraser Basin Council, Canada}

- Murray-Darling Basin Commission, Australia

- Tennessee Valley Authority, USA

- US Environmental Protection Agency

- World Resources Institute.

Each of these and their approaches to developing indicators are described briefly below.

\section{Fraser Basin Council}

The Fraser River Basin in Canada covers a quarter of British Columbia's land mass, with an area of $240000 \mathrm{~km}^{2}$. The river itself is $1375 \mathrm{~km}$ long from the headwaters to the mouth and is the fifth longest in Canada. It supports two-thirds of the province's population and accounts for $80 \%$ of its Gross Geographic Product. The economy of the Basin has historically been dependent on the natural resource base with fishing, forestry, mining, and hydroelectric development being important activities. In addition, the Basin supports a diverse agricultural sector.

The Fraser Basin Council is a non-governmental, not-for-profit organisation. It was established in 1997 as the successor to the Fraser Basin Management Program, an intergovernmental coordination program that focused on the sustainability of the Fraser River Basin between 1992 and 1997. The Council is guided by a 36person Board of Directors that represent all four orders of Canadian governance (i.e. federal, provincial, local government and First Nations), as well as non-government and private sector interests. The work of the Council is carried out by co-ordinators in each of the five regions of the Basin.

The mandate of the Council is to enable individuals, organisations and governments of the Fraser Basin to work together to advance the sustainability of the Basin. The Council's work is guided by its Charter for Sustainability, with its vision that states: "the Basin is a place where social well-being is supported by a vibrant economy and sustained by a healthy environment" (Fraser Basin Council, 1997). The Charter contains 26 goals related to social, economic, environmental and institutional systems in the Basin. The goals are organised under four directions or themes: understanding sustainability; caring for ecosystems; strengthening communities and improving decision-making.

The constitution of the Council requires that it report to the residents of the Fraser Basin at regular intervals on the progress 


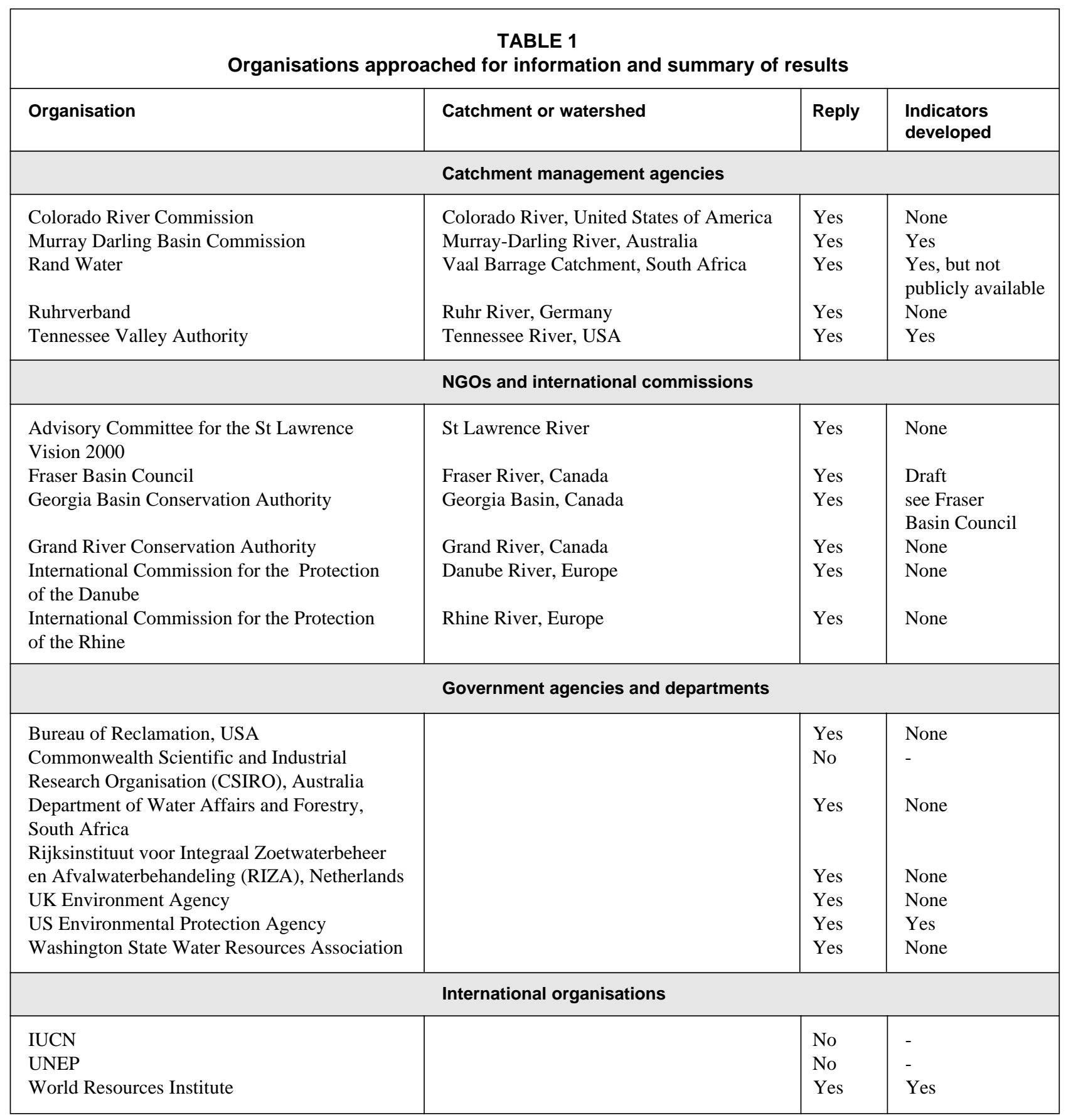

towards sustainability. The use of sustainability indicators was recognised as an important tool to accomplish this. The Council is currently in the process of identifying a set of sustainability indicators and has, thus far, developed a draft set of 40 indicators using the Council's Charter for Sustainability (Fraser Basin Council, 1997) as a framework.

The indicators chosen are goal-oriented towards the 26 goals of the Charter under the four directions specified by the Charter. A discussion document in the form of a workbook (Fraser Basin Council, 2000) has been developed. This will form the basis of a participatory process (including workshops and an on-line indicators questionnaire) to refine and further develop the indicators presented in the workbook. The indicators available for evaluation at this stage are still a preliminary set, which will be refined by the middle of 2001. For the purpose of the evaluation, the draft indicators will be used.

\section{Murray-Darling Basin Commission}

The Murray-Darling River system drains about $14 \%$ of the Australian continent, covering a catchment area of $1061469 \mathrm{~km}^{2}$ (Crabb, 1997). It is a highly-utilised basin, with about $81 \%$ of the divertible water having been developed (Commonwealth of Australia, 1996). The Murray-Darling Basin Commission (MDBC) was established in 1988 and is responsible for co-ordinating the efforts of the governments (Commonwealth, New South Wales, Victoria, South Australia and Queensland) and communities involved in the management of the Basin. 
As part of its mandate to manage the natural resources of the Murray-Darling system, the MDBC has developed the Basin Sustainability Plan (BSP; prior to 2001 this was entitled the Basin Sustainability Program), the aim of which is "to promote and coordinate effective planning and management for the equitable, efficient and sustainable use of the water, land and other environmental resources of the Murray-Darling"(MDBC, 2000a). The BSP is largely administered through three programmes:

- Riverine Environment Management

- Irrigated Regions Management

- Dryland Regions Management.

The BSP also has four key result areas:

- Water quality

- Sustainable agricultural production

- Nature conservation

- Cultural heritage (introduced in late 1999).

Each programme is required to address specific objectives within each key result area. In addition, the BSP has a set of directionsetting objectives that are shared by all programs. These relate to: government and community capacity development, community empowerment, and development of co-ordinating frameworks.

In 1998, the Commission attempted to develop a set of indicators for assessing progress towards the BSP objectives. Given the multijurisdictional nature of the administration of the Murray-Darling Basin, it was essential that data sets in each jurisdiction were sufficiently compatible (or capable of being made so) to generate basin-wide indicators.

An initial set of 130 indicators generated by the Commission, was reduced to 30 (MDBC, 1999). These were tested to evaluate their efficacy, the cost of generating data, and the administrative requirements to align existing data sets in the six jurisdictions. Of the 30 , only 16 were recommended for use in the Basin and, of these, only 5 were suitable for rapid implementation due to the general lack of compatible basin-wide data sets. The majority of the 16 indicators recommended dealt with the quality, state and use of aquifers and surface water. The evaluation of indicators in this paper included all 30 indicators tested by the MDBC.

The Commission is now working towards implementing a goal-oriented framework within which indicators will be developed further. In particular, the partners of the MDBC are in the process of agreeing to a new Integrated Catchment Management (ICM) Framework (MDBC, 2000b). When finalised and approved by the partner governments this framework will commit all stakeholders in the Basin to:

- developing a range of basin-wide strategies regarding the management of salinity, water quality, water sharing, riverine ecosystem heath, and terrestrial biodiversity;

- establishing and further developing the capacities of Catchment Management Organisations across the Basin;

- strengthening links between land-use planning legislation and processes and catchment planning and management;

- establishing a range of basin-wide and catchment-level targets, initially these will be for water quality, water sharing, terrestrial biodiversity and river ecosystem health; and

- developing a set of core indicators of catchment health to complement the targets as a means of assessing progress and directing investments and effort to achieve major benefits for the Basin.
In terms of indicators, the development of this ICM Framework represents a shift from previous attempts to utilise only pre-existing data sets and interpretive models such as Pressure-State-Response (PSR) framework. Instead, the ICM Framework will:

- identify the data and indicators needed for catchment management, investment targeting, and accountability purposes, and

- provide the structure for the development of basin-wide and regional-level reporting processes.

\section{Tennessee Valley Authority}

The Tennessee River in the Eastern United States is the 5th largest river in the country, and the Tennessee River Valley covers an area of about $103600 \mathrm{~km}^{2}$ within seven states. The Tennessee Valley Authority (TVA), created by the US Congress in 1933 to manage the system, has three main goals:

- supplying low-cost, reliable power to the nearly eight million people living in the region;

- stimulating economic growth, and

- supporting a thriving river system.

As part of the environmental stewardship of the river, the TVA has established a citizen advisory council (the Regional Resource Stewardship Council) as well as twelve Watershed Teams whose aim is to improve watershed conditions in the Tennessee Valley.

The TVA has established a set of core performance indicators for each of the three main goals mentioned above, including "supporting a thriving river system", as part of the Strategic Plan for 2000 to 2005 (TVA, 2000). The indicators supporting this goal provide the basis for catchment management within the Tennessee River. The main objectives within the thriving river system goal are to minimise flood damage, maintain navigation, support power production, improve water quality, protect public health, protect the environment and support recreational uses.

Within this Strategic Plan, the TVA has developed a set of indicators that primarily deal with watershed condition in terms of water quality. The approach that they have taken is twofold:

- A Watershed Condition Index is used to assess the overall water quality conditions as an outcome measure. It is based on four physical elements: i.e. reservoir ecological health; stream ecological health; water quality assessments, and reservoir shoreline vegetation condition.

- A planning framework used by the Watershed Teams is aimed at meeting the outcome by focusing on four core stewardship areas of the TVA, i.e. shoreline management, water resource condition, public lands management, and stakeholder or customer interests. This framework allows for development project evaluation based on natural resource conditions (13 measures) and public interests (16 measures), which build toward overall watershed sustainability.

\section{US Environmental Protection Agency}

The EPA is a United States federal government organisation, which was established in 1970. Its mission is "the establishment and enforcement of environmental protection standards consistent with national environmental goals...The conduct of research on the adverse effects of pollution and on methods and equipment for controlling it; the gathering of information on pollution; and the use 
of this information in strengthening environmental protection programmes and recommending policy changes...assisting others, through grants, technical assistance and other means, in arresting pollution of the environment...assisting the Council on Environmental Quality in developing and recommending to the President new policies for the protection of the environment." (EPA, 2001).

The EPA has established a set of 12 national environmental goals, of which two are "safe drinking water" and "clean waters". To check progress towards the national goals, the EPA developed a series of milestones for each goal that set a 10-year target to be reached by 2005 . In addition five objectives for meeting the goals have been set. These are: conserve and enhance public health; conserve and enhance ecosystems; support uses designated by the states and tribes in their water quality standards; conserve and improve ambient conditions, and prevent or reduce pollutant loadings and other stressors. In 1996 the EPA, in collaboration with other government organisations, developed a set of indicators to meet the goals, milestones and objectives of the organisation (EPA, 1996). Eighteen indicators were chosen. These were used as a basis for the current Index of Watershed Indicators (EPA, 2001)

Development of the Index of Watershed Indicators was aimed at providing a complete descriptive technique for characterising the condition and vulnerability of water resources at a catchment level; establishing a national baseline on the condition and vulnerability of aquatic resources, and making information readily available (EPA, 2001). The 15 indicators chosen to achieve these aims have been split into "condition indicators" (i.e. state indicators) and "vulnerability indicators" (pressure indicators). There is ongoing development of these indicators, especially with regard to policy and institutional indicators that will eventually be added to the set (EPA, 2001).

\section{World Resources Institute}

The World Resources Institute, established in 1982, is an environmental "think-tank" based in Washington DC. Its mission is "to move human society to live in ways that protect Earth's environment and its capacity to provide for the needs and aspirations of current and future generations" (WRI, 2001). Its goals are to reverse the rapid degradation of ecosystems; to halt the changes in the earth's climate; to catalyse the adoption of policies and practices that expand prosperity, while reducing the use of materials and generation of wastes, and to guarantee people's access to information and decisions regarding natural resources and the environment (WRI, 2001).

Within the information programme of the WRI, a set of 15 indicators have been developed that characterise catchments in terms of their ecological value, current condition and vulnerability to potential degradation from human activities. The indicators have been developed as a preliminary set to provide information about major watersheds on a global scale. The set of 15 indicators incorporates 23 data sets that measure catchment characteristics and human activities that potentially affect rivers and lakes. The global data sets include such variables as land use, land cover, aridity, forest extent and loss, erosion, endemic bird species distributions, population density, and protected areas. Additional statistical databases on surface water runoff, location of major dams, and fish species diversity, were included when they could be georeferenced or linked to major rivers or lakes. The WRI has also recently completed additional indicators on the condition of the world's freshwater systems, where condition is defined as the current and future capacity of the systems to continue providing the full range of goods and services needed or valued by humans (Revenga et al., 2000).

\section{Comparison of indicator sets}

A direct comparison was made of the catchment indicators developed by each organisation (see Appendix A). Although the governance level of the organisations differs, the level of information required is the same (i.e. catchment level). The authors believe that the differences between the organisations make identification of the common issues for which indicators need to be developed all the more important, whilst the differences are less relevant. Thus, this analysis concentrates on the similarities rather than the differences.

The indicators were split into five water management themes: socio-economic, water balance, waste and pollution, resource condition, and policy and management (Walmsley, 2000). Within each of these categories, the indicators were split into categories, which were felt best reflected their aim. The categories that were represented in the five indicator sets under review included:

\section{Socio-economic}

- Population and demographics, which includes population growth and demographic changes within catchments, and can include birth and mortality rates, gender ratios and race ratios.

- Education of the catchment population, which includes levels of education and literacy.

- Employment, including sectoral and regional changes in employment and the job market.

- Community development, which includes issues such as community participation, charitable works, as well as crime rates.

- Economic development, which includes economic growth within the catchment, strategies for development, energy consumption and transportation.

\section{Water balance}

- Water availability, which is the amount of water available for use from surface and ground water sources. It includes climate as well as forms of hydrological modification and storage systems;

- Water use, is the sectoral and regional use of water, which includes abstraction of water as well as exporting of water from the basin.

\section{Waste and pollution}

- Waste production, which is the amount of waste produced within the catchment area. In this case it includes waste that enters waste treatment plants and landfill sites, as well as polluted runoff. It also includes compliance with pollution and water quality standards.

- Water quality, which is the condition of the water in terms of the possible chemical and physical pollutants that enter it.

\section{Resource condition}

- Biodiversity and ecosystem integrity, which includes aquatic ecosystem and species diversity, as well as changes in habitat and aquatic ecosystem health.

- Land use change, which includes changes to the terrestrial ecosystems which may impact on the catchment water resources. 


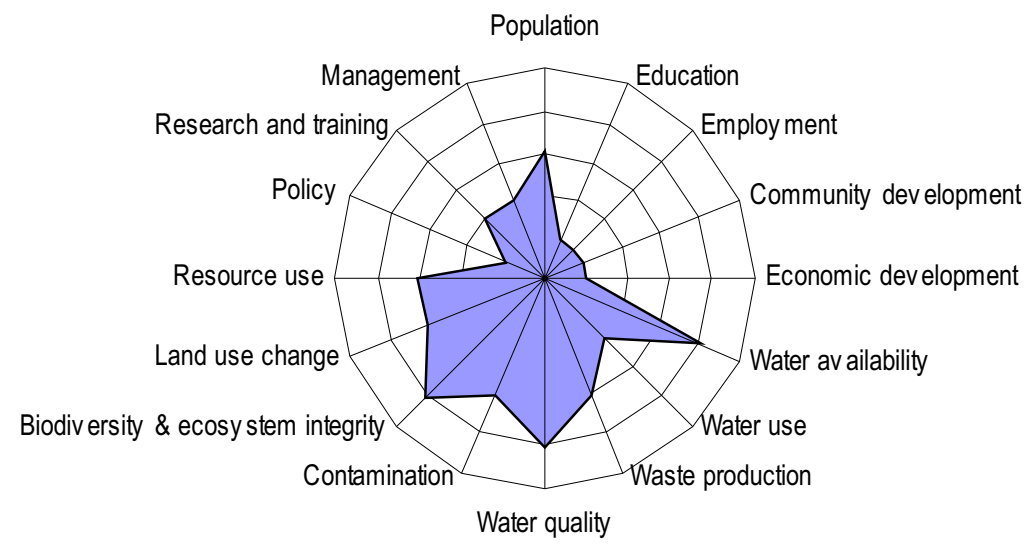

Figure 1

Number of organisations (0-5) that had indicators within each category

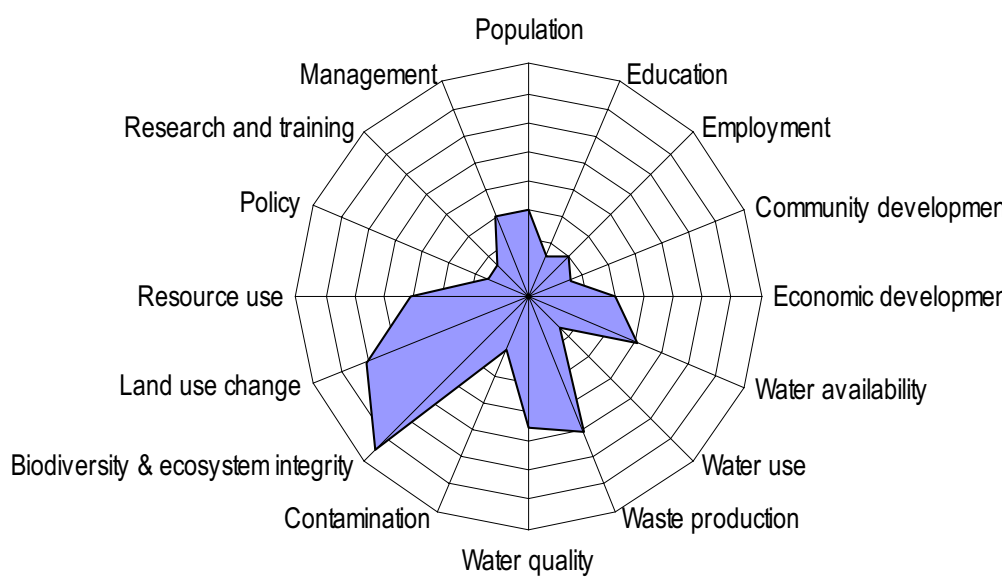

Figure 2

Number of indicators (0-16) within each category

- Resource use, which is the consumptive and non-consumptive use of resources that rely on aquatic systems for their continued existence. Consumptive uses include the harvesting of reeds, fish etc., whilst non-consumptive uses include shipping and recreation.

\section{Policy and management}

- Policy, which provides legislated and non-legislated guidelines for management, as well as determining the interaction among various political entities.

- Management, which determines the day-to-day running of the catchment within the policy framework.

- Research and training, which provides the knowledge on which further management steps will be taken.

Using these categories, it was possible to compare the indicator sets at three levels:

- number of organisations that had developed at least one indicator in each category (Fig. 1);

- total number of indicators that had been developed by the five organisations in each category (Fig. 2); and

- identification of common indicators (Table 2).
Figure 1 shows that the most common categories, which were included in the indicator sets of the five organisations, were biodiversity and ecosystem integrity, water quality and water availability. These were followed by population, resource use, land-use change, contamination and waste production, which were included in three of the sets.

A similar pattern was observed with the number of indicators per category (Fig. 2), with biodiversity and ecosystem integrity having the highest number of indicators (15), followed by land- use change (12), waste production (10), water quality (9), resource use (8) and water availability (8). Population, economic development, contamination and management had 6 indicators in each, whilst education, community development, research and training and water use had the fewest indicators (3).

The level of importance of each category can be assessed by summing the scores from the above two analyses to provide an index of importance (Fig. 3). Figure 3 shows that biodiversity and ecosystem integrity, land use change, water quality, waste production, water availability and resource use are common categories, and are valuable at all levels of governance.

Common indicators were also identified (Table 2). In each case, the indicator of one organisation did not have to be identical to a similar one in another organisation. However, if the sense behind the indicator was considered to be similar, it was assumed that there was commonality.

\section{Discussion}

From the response to the survey by the 21 organisations approached (see Table 1), it is apparent that not many had developed sets of indicators for catchment management purposes. This is unexpected as the need for integrated catchment and water resource management is recognised throughout the world (DWAF and WRC, 1996), and indicators are the ideal means by tracking changes in catchment conditions, and thus providing information for decision-making. There were a variety of reasons for this, including: the complexity of developing indicator sets for international catchments (e.g. Danube River; Helmut Fleckseder, Danube PCU, pers. comm.); the lack of resources, and the lack of understanding of the use of indicators in catchment water resource management. However, even the five sets of indicators that were available provided an indication of some of the issues that need to be taken cognisance of while developing indicator sets for catchment management, as discussed below.

\section{Frameworks}

Indicators need to meet the requirements of the physical system under inspection. For instance, the functional aspects of the Fraser River and Murray Darling differ considerably, and certain key physical characteristics need to be taken into account to ensure that these are represented. In the Fraser River this may mean understanding the ecological requirements of the sockeye salmon and the influence of the natural forests on the system, whilst in the Murray-Darling system salinity is a major problem that requires understanding. These should be reflected in the indicators chosen. 
Biodiversity \& ecosystem integrity

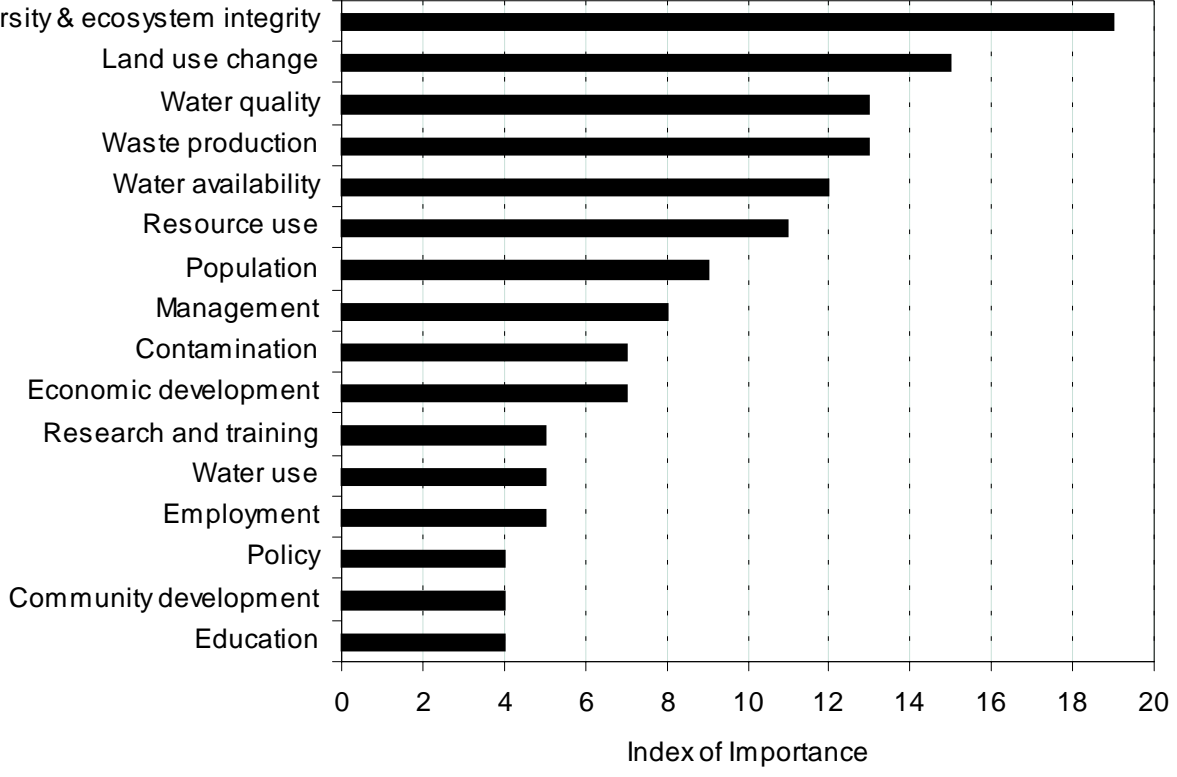

Figure 3

Index of importance for the various indicator categories

TABLE 2

List of indicators found in more than one indicator set

\begin{tabular}{|l|l|l|l|l|}
\hline Socio-economic & Water balance & Waste and pollution & Resource condition \\
\hline $\begin{array}{l}\text { Population growth } \\
\text { Community involvement }\end{array}$ & $\begin{array}{l}\text { Water availability } \\
\text { Water use }\end{array}$ & $\begin{array}{l}\text { Water quality trends } \\
\text { Soil contamination } \\
\text { Non-compliance }\end{array}$ & $\begin{array}{l}\text { Species at risk } \\
\text { Key species assessment } \\
\text { Change in vegetation } \\
\text { Agricultural impact } \\
\text { Access to recreational opportunities } \\
\text { Ecosystem health }\end{array}$ \\
\hline
\end{tabular}

Therefore, a clear understanding of the physical environmental interactions and their socio-economic importance is required to develop a coherent set of indicators.

Walmsley (2002) has shown that one method of doing this is through the use of indicator frameworks such as the Pressure-StateResponse (PSR) framework (Hammond et al., 1995; Gouzee et al., 1995) or the Driving-forces-Pressure-State-Impact-Response (DPSIR) framework (Smeets and Weterings, 1999). Both the PSR and DPSIR frameworks have been used extensively in the development of state-of-the-environment reports (DEAT, 1999). These physical frameworks tend to be used most often for identification of environmental indicators, and deal more specifically with natural environmental issues and the influence of humans on the environment.

More recently, issues-based frameworks have been used to identify indicators. These frameworks, as their name suggests, are based on the identification of strategic issues that will influence the sustainability of a system (country, province, region, catchment, etc.). They rest upon the premise that not all issues are equally important at any given time. Thus, they are dynamic and will change over time as the priority issues are dealt with and other issues emerge.

Of the five indicator sets under review, the only one for which there was an obvious framework for development was the Fraser Basin set. These were developed from the Council's Sustainability Charter, which caters for all sustainability issues in the basin. It provides an adequate framework for a set of sustainability indicators. The lack of an obvious framework in the other sets of indicators may stem from the indicators being developed primarily from a needs analysis, leading to issue-based indicators.

The use of one framework, does not preclude the use of another. It is recommended for South Africa that the physical and issuesbased frameworks used in conjunction with each other to develop indicators that not only take into account the characteristics of the physical system, but also concentrate on current or emerging issues that will affect the future sustainability of any catchment.

In terms of the physical requirements, Walmsley (2002) has developed a method for selecting indicators for catchment management using the DPSIR framework (see also Walmsley et al., 1999), which can readily be used for developing indicators in South Africa. The framework is useful to identify interactions between various elements of a catchment, and if core (or key) indicators are identified within each of the categories, most major catchment-based management issues will be covered.

The themes identified by Walmsley (2002) include:

- Driving forces

Natural conditions

Development and economic activity

- Pressures

Water supply

Water demand

Waste and pollution 
- State

Water quality

- Impacts

Ecosystem Integrity

Use value

- Responses

Policy and management, including

institutional arrangements.

\section{Themes and indicators}

The indicator sets evaluated in this paper were different from each other. However, there were several recurring themes and indicators (see Figs. 1 to 3; Table 2). These give an indication of the common problems with regard to sustainability of water resources, and some of the key issues that need to be addressed for adequate catchment management. If the common themes are combined with the common indicators (Table 3), certain key issues emerge that should be considered for inclusion in a catchment sustainability indicator set for South Africa. These include:

- The destruction of ecosystem integrity, which may lead to biodiversity and habitat loss. These can be assessed through monitoring of high-risk species and key species or community assessments.

- Waste production, which is recognised as a major problem in both developing and developed countries. It leads to pollution of the environment and a deterioration in water quality.

- Water quality problems derived from excess pollutants entering freshwater systems. In South Africa these may include eutrophication, salinisation, microbiological deterioration, toxic pollutants and sedimentation.

- Resource use, in particular, access to the resource for recreational purposes, although in South Africa harvesting of the resources may be as important.

- Terrestrial ecosystem condition, which will have an impact on the water resource of the catchment.

- Population growth, which has far-reaching repercussions in terms of development requirements, resource use and sustainability of a system.

All of the themes and indicators presented in Table 3 can be applied to the South African situation, and could provide a basis against which to assess a South African indicator set.

\section{Policy requirements of indicator sets}

One of the reasons for the differences in indicator sets in general is that they are a reflection of policy, both national and organisational, upon which they have been based. In this instance:

- The Fraser Basin indicators focus on the need for sustainability, and are the best reflection of Integrated Catchment Management in the true sense of the term.

- The MDBC indicators reflect a policy of integrated water resource management and are based primarily on the management of the water resources, rather than the integration of all resources.
TABLE 3

Key themes and common indicators within these themes

\begin{tabular}{|l|l|}
\hline Theme & Indicator \\
\hline Biodiversity and ecosystem integrity & $\begin{array}{l}\text { Species at risk } \\
\text { Key species assessment }\end{array}$ \\
\hline Waste production & $\begin{array}{l}\text { Amount of waste produced } \\
\text { Compliance levels }\end{array}$ \\
\hline Water quality & Water quality trends \\
\hline Water balance & $\begin{array}{l}\text { Amount available } \\
\text { Water use }\end{array}$ \\
\hline Resource use & Access to recreational opportunities \\
\hline Land-use change & $\begin{array}{l}\text { Change in vegetation } \\
\text { Agricultural impact }\end{array}$ \\
\hline Terrestrial ecosystem condition & $\begin{array}{l}\text { Soil contamination } \\
\text { Ecosystem health }\end{array}$ \\
\hline Social issues & $\begin{array}{l}\text { Population change } \\
\text { Community involvement }\end{array}$ \\
\hline
\end{tabular}

- The TVA indicators reflect mainly the anthropocentric needs. - The US EPA indicators reflect their mandate to concentrate primarily on pollution control and management, rather than integrated catchment management.

One of the essential requirements of developing catchment indicators for South Africa is to ensure that they reflect the water resources and environment policies of the country. South Africa has recently undergone major transition in terms of both the water and environmental law in the country. The new legislation is underpinned by the concept of sustainability and any indicators based on the legislation could provide information on the progress towards environmental sustainability within the catchment context.

Key environmental legislation in South Africa includes the National Water Act (No 36 of 1998) and the National Environmental Management Act (No 107 of 1998). Other legislation and policy that may influence the choice of indicators will be: the National Forests Act (No 84 of 1998); the Marine Living Resources Act (No 18 of 1998); the White Paper on Integrated Pollution and Waste Management (March 2000); the White Paper on Minerals and Mining Policy (October 1998), and the White Paper on the Conservation and Sustainable Use of South Africa's Biological Diversity Policy (July 1997)

In particular, the National Water Act (No 36 of 1998) highlights certain issues for which indicators would need to be developed, including:

- Scarce and uneven distribution of natural water resources (water use and allocation; provision of water for basic human and ecosystem requirements; supply and demand management; meeting international requirements).

- Deteriorating water quality (pollution prevention; waste management).

- Deteriorating water resource and ecosystem quality (attaining resource quality objectives; atmospheric conditions).

- Increase in natural catastrophic events (floods and droughts). 


\section{Stakeholder involvement}

A common thread to all the indicator sets was the participation of stakeholders (who influence or will be affected by management of the catchment) in their development. Although expert opinion is required to develop a set of indicators, the core indicators that are finally decided upon, should meet the requirements of stakeholders in the catchment. Obviously indicator sets cannot meet all the needs of all the stakeholders, but an attempt should be made to include the requirements of stakeholders in general. In South Africa, structures have been set up in many catchments for the involvement of stakeholders. Catchment Management Forums have either been set up, or are being set up for most of the highly-developed and sensitive catchments (e.g. Upper Olifants River, Mpumalanga and Palmiet, Western Cape). Likewise, management of the water resources of South Africa at catchment level has been delegated to regional offices of DWAF. Stakeholders who should be approached with regard to the development of indicators for sustainable catchment management include DWAF regional offices; water service providers such as Umgeni Water and Rand Water; local authorities; catchment management agencies and water forums.

\section{Data availability}

One of the issues that arose in the development of the indicator sets under review is that the development of indicator sets is often limited by data availability, and indicators are selected for data availability rather than for validity. The WRI indicator set, for instance, was largely based on the amount of data available worldwide, and is limited by some fairly gross-scale indicators. If, however, a core indicator set is developed that takes into account the physical system as well as the policy and management goals, the collection of data should be important enough that monitoring programmes be put in place. The selection of indicators should not rely on data availability, but should be guided by what is available, or what can be collected within reasonable cost, effort and timeframe.

\section{Conclusion}

From the review of international initiatives to develop sustainability indicators for catchment management, it is apparent that each situation is unique, and that no two indicator sets will be alike. It is possible to identify some broad criteria for the development of sustainability indicators for catchments in South Africa:

- Indicators should be relevant in terms of the current policy and management issues that affect catchment sustainability.

- Indicators should reflect the physical characteristics of catchments and the human influences on these (i.e. integrated water resource management).

- The selection of indicators should not rely on data availability, but should be guided by what is available, or what can be collected within reasonable cost, effort and timeframe.

- The indicator set developed should be useful for major stakeholders involved in catchment management, such as DWAF, catchment management agencies, local authorities and service providers.

\section{Acknowledgements}

This review would not have been possible without the co-operation and help of colleagues throughout the world whom we have not even met in person. The authors extend special thanks to:
Patricia Chambers, Environment Canada

Helmut Fleckseder, Danube PCU

Bruce Kay, Georgia Basin Ecosystem Initiative, Environment Canada

Jane Kinniburgh, Environment Agency

Pete Mason, Grand River Conservation Authority

Mark Nelson, Bureau of Reclamation

Ernst Nusch, Ruhrverband

Guy Tremblay, Advisory Committee, St Lawrence Vision 2000

Ronald van Dokkum, Rijksinstituut voor Integraal Zoetwaterbeheer en Afvalwaterbehandeling

Karin Zambra, Danube PCU.

We would also like to thank Mr Maitland Seaman (Centre for Environmental Management, University of the Free State) and Dr Danny Walmsley (Mzuri Consultants, Pretoria) for their comments and support.

\section{References}

AUSTRALIAN AND NEW ZEALAND ENVIRONMENT AND CONSERVATION COUNCIL (ANZECC) (1998) Core Environmental Indicators for Reporting on the State of the Environment: Discussion Paper for Public Comment. ANZECC, Canberra. 63 pp.

BAKKES JA, VAN DEN BORN GJ, HELDER JC, SWART RJ, HOPE CW and PARKER JDE (1994) An Overview of Environmental Indicators: State of the Art and Perspectives. Environmental Assessment Sub-Programme, Nairobi. 73 pp.

COMMONWEALTH OF AUSTRALIA (1996) Australia State of the Environment. CSIRO Publishing, Collingwood.

CSIR, HSRC and MZURI CONSULTANTS (2001) Development of a Core Set of Indicators for the Purpose of Reporting on the State of the Environment at National and State Levels. Scoping Document. Department of Environmental Affairs and Tourism, Pretoria.

CRABB P (1997) Murray-Darling Basin Resources: Murray-Darling Basin by Numbers. MDBC, Canberra.

DEPARTMENT OF ENVIRONMENTAL AFFAIRS AND TOURISM (DEAT) (1999) State of the Environment South Africa. DEAT, Pretoria.

DEPARTMENT OF WATER AFFAIRS AND FORESTRY (DWAF) and WATER RESEARCH COMMISSION (WRC) (1996) The Philosophy and Practice of Integrated Catchment Management: Implications for Water Resource Management in South Africa. WRC Report No TT $81 / 96$.

EERONHEIMO O, AHTI A and SAHLBERG S (1997) Criteria and Indicators for Sustainable Forest Management in Finland. Ministry of Agriculture and Forestry, Helsinki. 70 pp.

ENVIRONMENTAL PROTECTION AGENCY (EPA) (1996) Environmental Indicators of Water Quality in the United States. EPA, Washington DC. 25 pp.

ENVIRONMENTAL PROTECTION AGENCY (EPA) (2001) United States Environmental Protection Agency (www.epa.gov.).

FOOD AND AGRICULTURE ORGANISATION(FAO) (1992) Yearbook Fishery Statistics. FAO, Rome.

FRASER BASIN COUNCIL (1997) Fraser Basin Council Charter for Sustainability. Fraser Basin Council, Vancouver, BC.

FRASER BASIN COUNCIL (2000) Fraser Basin Council Sustainability Indicators Workbook. Fraser Basin Council, Vancouver, BC. 45 pp.

GOUZEEN, MAZIJN B and BILLHARZS (1995) Indicators of Sustainable Developmentfor Decision-Making. Federal Planning Office of Belgium, Brussels. 34 pp.

GRID-ARENDAL (2001) GRID-Arendal State of the Environment Reports (www.grida.no/soe.).

HAMMOND A, ADRIAANSE A, RODENBURG E, BRYANT D and WOODWARD R (1995) Environmental Indicators: A Systematic Approach to Measuring and Reporting on Environmental Policy Performance in the Context of Sustainable Development. World Resources Institute, Washington. $42 \mathrm{pp}$. 
MACGILLIVRAY A (1994) Environmental Measures: Indicators for the UK Environment. Royal Society for the Protection of Birds, Bedfordshire, UK. 107 pp.

MOLDAN B and BILLHARZ S (eds.) (1997) Sustainability Indicators: A Report on the Project on Indicators of Sustainability. John Wiley and Sons, New York. 415 pp.

MURRAY-DARLING BASIN COMMISSION (MDBC) (1999) Performance Indicators for the Murray-Darling Basin Sustainability Program: Final Project Report. Murray-Darling Basin Commission, Canberra.

MURRAY-DARLING BASIN COMMISSION (MDBC) (2000a) The Basin sustainability program. In: Basin Sustainability Program Reporting Guidelines Kit, August 2000. Murray-Darling Basin Commission, Canberra.

MURRAY-DARLING BASIN COMMISSION (MDBC) (2000b) Integrated Catchment Management in the Murray-Darling Basin, 2001-2010: Delivering sustainable development. Murray-Darling Basin Commission, Canberra.

OBST C (2000) Report of the September 1999 OECD Expert Workshop on the measurement of sustainable development. In: Organisation for Economic Co-operation and Develoment: Framework to Measure Sustainable Development. OECD, Paris. 7-17.

ORGANISATION FOR ECONOMIC CO-OPERATION AND DEVELOPMENT (OECD) (1991) The State of the Environment. OECD, Paris.

ORGANISATION FOR ECONOMIC CO-OPERATION AND DEVELOPMENT (OECD) (1993) Environmental Indicators: Basic Concepts and Terminology. Background Paper No 1 OECD, Paris. 150 pp.

REVENGA C, BRUNNER J, HENNINGER N, KASSEM K and PAYNE R (2000) Pilot Analysis of Global Ecosystems: Freshwater Systems.
World Resources Institute, Washington, DC. 83 pp.

SMEETS E and WETERINGS R (1999). Environmental Indicators: Typology and Overview. Technical Report No 25. European Environmental Agency, Copenhagen. 19 pp.

TENNESSEE VALLEY AUTHORITY (TVA) (2000) Government Performance and Results Act (GPRA): Strategic Plan FY 2000-2005. Tennessee Valley Authority, Chattanooga. 27 pp.

TRZYNA TC (ed.) (1995) A Sustainable World. IUCN, The World Conservation Union. 272 pp.

UNITED NATIONS ENVIRONMENT PROGRAMME (UNEP) and WORLD HEALTH ORGANISATION (WHO) (1988) Assessment of Urban Air Quality Worldwide. UNEP, Nairobi, Geneva.

WELLS J (1992) Pre-Impoundment Study of the Biological Diversity of the Benthic Macro-Invertebrate Fauna of the Sabie-Sand River System. M.Sc. Thesis, Univ. of Cape Town. 207 pp.

WALMSLEY JJ, WALMSLEY RD and SILBERBAUER M(1999) Chapter 3: Freshwater systems. In: State of the Environment South Africa. DEAT, Pretoria.

WALMSLEY JJ (2000) Catchment Diagnostic Framework. Development of the Catchment Diagnostic Index. Rand Water, Johannesburg.

WALMSLEY JJ(2002) Framework for measuring sustainable development in catchment systems. Environ. Manage. 29.

WARD CJ (1990) Environment Indicators for State of the Environment Reporting. Information Paper No 21, Centre for Resource Management, Canterbury, New Zealand.

WORLD BANK (1995) Monitoring Environmental Progress. The World Bank, Washington DC. 84 pp.

WORLD RESOURCES INSTITUTE (WRI) (2001) World Resources Institute (www/wri.org.)

\begin{tabular}{|c|c|c|c|c|c|}
\hline \multicolumn{6}{|c|}{$\begin{array}{l}\text { APPENDIX A } \\
\text { List of indicators from the five response organisations, categorised according to five themes and further split } \\
\text { into categories under each theme }\end{array}$} \\
\hline & $\begin{array}{l}\text { Fraser Basin } \\
\text { Council (Draft } \\
\text { Indicators) }\end{array}$ & $\begin{array}{l}\text { Murray Darling } \\
\text { Basin Commission } \\
\text { (R) = Recommended }\end{array}$ & $\begin{array}{l}\text { Tennessee Valley } \\
\text { Authority }\end{array}$ & $\begin{array}{l}\text { US Environmental } \\
\text { Protection Agency }\end{array}$ & $\begin{array}{l}\text { World Resources } \\
\text { Institute }\end{array}$ \\
\hline \multicolumn{6}{|c|}{ Socio-economic } \\
\hline Population & $\begin{array}{l}\text { Population outside } \\
\text { growth concentration } \\
\text { area } \\
\text { Mortality rates } \\
\text { Legislator's reflection } \\
\text { of population }\end{array}$ & & & Population change & $\begin{array}{l}\text { Urban population } \\
\text { growth } \\
\text { Population density }\end{array}$ \\
\hline Education & $\begin{array}{l}\text { Newspaper circulation } \\
\text { Connection to internet } \\
\text { Levels of education }\end{array}$ & & & & \\
\hline Employment & $\begin{array}{l}\text { Income rates } \\
\text { Employment inside and } \\
\text { outside growth } \\
\text { concentration area } \\
\text { Aboriginal employment } \\
\text { rates } \\
\text { Jobs by sector }\end{array}$ & & & & \\
\hline $\begin{array}{l}\text { Community } \\
\text { development }\end{array}$ & $\begin{array}{l}\text { Membership in volun- } \\
\text { tary or community } \\
\text { organisations } \\
\text { Charitable donations } \\
\text { Crime rates }\end{array}$ & & & & \\
\hline $\begin{array}{l}\text { Economic } \\
\text { development }\end{array}$ & $\begin{array}{l}\text { Investment in public } \\
\text { assets } \\
\text { Economic diversity index } \\
\text { Adoption of regional } \\
\text { growth strategy } \\
\text { Public transit ridership } \\
\text { Vehicle ownership per } \\
\text { household } \\
\text { Total and alternate } \\
\text { energy consumption }\end{array}$ & & & & \\
\hline
\end{tabular}




\begin{tabular}{|c|c|c|c|c|c|}
\hline \multicolumn{6}{|c|}{ Water balance } \\
\hline $\begin{array}{l}\text { Water availability } \\
\text { Water use }\end{array}$ & Per capita water use & $\begin{array}{l}\text { Area underlain by } \\
\text { shallow water tables, } \\
\text { and areas where water } \\
\text { tables are rising }(\mathrm{R}) \\
\\
\text { Average water diversion } \\
\text { from the Basin (R) } \\
\text { Ratio of water extracted } \\
\text { to water available, } \\
\text { including groundwater }\end{array}$ & $\begin{array}{l}\text { Flood storage } \\
\text { availability } \\
\text { Discretionary } \\
\text { zone attainment }\end{array}$ & $\begin{array}{l}\text { Hydrologic modification - } \\
\text { dams }\end{array}$ & $\begin{array}{l}\text { Primary watersheds } \\
\text { Water availability } \\
\text { Aridity } \\
\text { Existing and proposed } \\
\text { major dams }\end{array}$ \\
\hline \multicolumn{6}{|c|}{ Waste \& pollution } \\
\hline $\begin{array}{l}\text { Waste } \\
\text { production }\end{array}$ & $\begin{array}{l}\text { Waste diverted from } \\
\text { landfills } \\
\text { Greenhouse gas emissions } \\
\text { Rate of non-compliance } \\
\text { in mining industry } \\
\text { Exceedance of acceptable } \\
\text { PM10 levels }\end{array}$ & $\begin{array}{l}\text { Number of waste treat- } \\
\text { ment plants with tertiary } \\
\text { treatments and nutrient } \\
\text { removal, together with } \\
\text { the volume of waste- } \\
\text { water released to } \\
\text { inland waters (R) } \\
\text { Reduction in phosphorus } \\
\text { loads discharged from } \\
\text { sewage treatment plants } \\
\text { and other point sources }\end{array}$ & & $\begin{array}{l}\text { Urban runoff potential } \\
\text { Index of agricultural } \\
\text { runoff potential } \\
\text { Pollutant loads discharged } \\
\text { above permitted } \\
\text { discharge limits - } \\
\text { toxic pollutants } \\
\text { Pollutant loads discharged } \\
\text { above permitted } \\
\text { discharge limits - } \\
\text { conventional pollutants }\end{array}$ & \\
\hline Water quality & Water quality trends & $\begin{array}{l}\text { Salinity and nitrate levels } \\
\text { in groundwater }(\mathrm{R}) \\
\text { Salinity levels in } \\
\text { surface water }(\mathrm{R}) \\
\text { Estimated concentrations } \\
\text { of phosphorus and } \\
\text { nitrogen in surface } \\
\text { waters }(\mathrm{R})\end{array}$ & $\begin{array}{l}\text { Watershed water quality } \\
\text { Dissolved oxygen } \\
\text { deficit due to forced } \\
\text { outages }\end{array}$ & $\begin{array}{l}\text { Ambient water quality - } \\
\text { four conventional } \\
\text { pollutants } \\
\text { Indicators of source } \\
\text { water quality for } \\
\text { drinking water systems } \\
\text { Ambient water quality } \\
\text { data - four toxic pollutants }\end{array}$ & \\
\hline Contamination & $\begin{array}{l}\text { Contaminants in great } \\
\text { blue heron eggs } \\
\text { Contaminated and } \\
\text { remediated mine sites }\end{array}$ & $\begin{array}{l}\text { Area of land that is } \\
\text { reported to have saline } \\
\text { soils with top meter, in } \\
\text { regions of Australia of } \\
>250 \mathrm{~mm} \text { annual } \\
\text { rainfall } ®\end{array}$ & & Contaminated sediments & \\
\hline \multicolumn{6}{|c|}{ Resource condition } \\
\hline $\begin{array}{l}\text { Biodiversity \& } \\
\text { ecosystem } \\
\text { integrity }\end{array}$ & $\begin{array}{l}\text { Total run size and } \\
\text { spawning escapement } \\
\text { of Fraser River sockeye } \\
\text { Status of salmonids } \\
\text { Percentage of known } \\
\text { species at risk }\end{array}$ & \begin{tabular}{|l|} 
Macroinvertebrate \\
assemblages in rivers \\
assessed by AUSRivAS \\
sampling protocols \& \\
computer models (R) \\
Conservation status \\
known for species, \\
ecological communities \\
and ecological processes \\
Change in abundance of \\
selected threatened or \\
high profile species or \\
communities \\
Length of stream (or \\
riparian zone) protected, \\
rehabilitated and/or re \\
stored through NHT \\
funded projects (R) \\
Percentage of total \\
stream length with \\
riparian vegetation per \\
drainage division
\end{tabular} & & $\begin{array}{l}\text { Aquatic/wetland species } \\
\text { at risk } \\
\text { Estuarine Pollution } \\
\text { Susceptibility Index } \\
\text { Wetland Loss Index }\end{array}$ & $\begin{array}{l}\text { Freshwater fish } \\
\text { species and endemism } \\
\text { Endemic bird areas } \\
\text { Area affected by } \\
\text { water erosion } \\
\text { Protected areas }\end{array}$ \\
\hline Land-use change & $\begin{array}{l}\text { Composition of forest } \\
\text { lands (i.e. age and } \\
\text { species distribution) } \\
\text { Farm practices (i.e. soil } \\
\text { conservation practices } \\
\text { and pesticide usage) }\end{array}$ & $\begin{array}{l}\text { Area of remnant } \\
\text { vegetation protected } \\
\text { and managed by } \\
\text { a) areas of formal reserves, } \\
\text { b) areas under manage- } \\
\text { ment or conservation } \\
\text { agreements } \\
\text { Area of native vegeta- } \\
\text { tion by type } \\
\text { Difference between } \\
\text { regional crop water } \\
\text { requirements and water } \\
\text { application }\end{array}$ & & & $\begin{array}{l}\text { Remaining original } \\
\text { forest cover } \\
\text { Extent of original } \\
\text { forest cover lost } \\
\text { Tropical deforestation } \\
\text { Cropland irrigation } \\
\text { Modified landscape } \\
\text { (cropland and } \\
\text { developed areas) }\end{array}$ \\
\hline
\end{tabular}




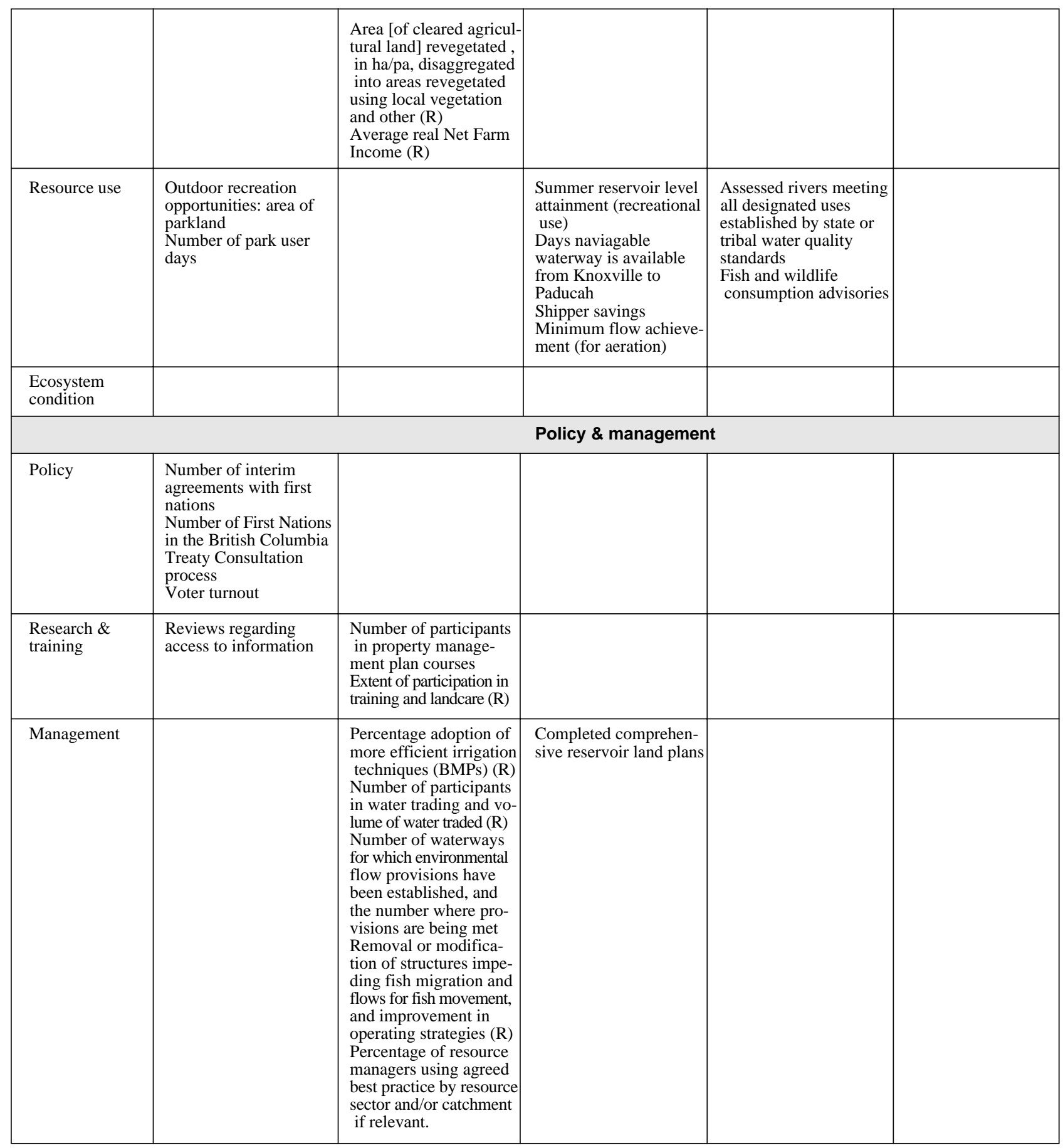

